\title{
The Analysis of Science Process Skills on Natural Science Questions at Elementary Schools
} in Tarakan

\author{
Muhsinah Annisa, Ratna Yulinda, Sucahyo Mas'an Al Wahid \\ Universitas Borneo Tarakan \\ Tarakan, Indonesia \\ echa.ok@gmail.com
}

\begin{abstract}
Education quality control, essentially, is a control to the human resources quality. This control effectiveness level should require information on students' conditions whether the change is available or not, the teachers work well or not, and the school supports the implementation of educational programs to achieve an optimal result or not. The assessment on learning is frequently overlooked, especially where the learning assessment is rather only performed to the results/scores than to the process skills in doing it; whereas, the formulation, implementation and evaluation should be done in balance and simultaneous. This study aimed to identify the fifth grade students' science process skills on natural science questions at elementary school in Tarakan city. This study deployed qualitative descriptive method. Purposive sampling was used as technique sampling in this study. Descriptive statistics with percentage technique was used as data analysis technique. From this study we concluded that in questions of the fifth grade elementary school students' natural science midterm exam questions, there are several aspects of natural science process skills, i.e. observing, classifying, inferring, predicting, and designing experiments. However, the most dominant of natural science process skills aspect that contained in the questions is observation aspect.
\end{abstract}

Keywords-Science for Elementary School, Science Process Skill, Question

\section{INTRODUCTION}

Education in Elementary Schools is the students' foundation to instill the basic knowledge that is developed. One of them is through teaching the Natural Science (IPA). The necessity to master the natural science teaching in accordance with the intellectual development level of students should be done early; especially, in order to absorb the development of knowledge and technology as well as how to think logically. The natural science itself that is frequently referred to the term of natural science education is a compulsory subject in elementary school. The nature of natural science is a science to study the symptoms through a series of processes known to the scientific process. This process is built on the scientific attitude and the results are manifested as a scientific product composed in three most important components, namely: concepts, principles and theories that should be applied universally. [1] argued that the learning of natural science in elementary school has some purposes as follows: (1) to gain the faith to the greatness of the Almighty God by the presence, beauty and order of His creation; (2) to develop knowledge and concepts of natural science understanding that are useful and can be applied in daily life; (3) to develop curiosity, positive attitudes and awareness of interplay relationship between science, environment, technology, and society; (4) to develop process skills to investigate the nature of surroundings, to solve the problems, and to make decisions; (5) to raise awareness to participate in preserving, maintaining, and conserving the natural environment; (6) to increase the awareness to appreciate the nature and its regularity as one of God's creation, and (7) to acquire knowledge, concepts, and skills of natural science as a basis to continue their education to junior high school.

Based on the goals of learning science in elementary school, which are to develop the process skills to investigate the surroundings nature, to solve the problems, and to make decisions, then, the school has a necessity to develop an assessment based on process skill. Process skills make the students to feel the nature of science and allow the students to do 'sciences'. Science process skills are overall scientific skills that focuse on both cognitive and psychomotor. They are used to find concepts or principles or theories in order to develop concepts that have existed before or to perform a denial to an invention or classification Indrawati in [2]. In other words, these skills can be used as a tool to discover and develop concepts, principles or theories.

Assessment using natural science process skills has already been developed, one of which is [3], entitled: "Pengembangan tes Keterampilan proses sains dasar SD/MI" (Development of basic natural science process skills test on Elementary School/Islamic Elementary School). The same research has also been done by [4] entitled: "pengembangan tes pengukur keterampilan proses sains pola divergen mata pelajaran biologi SMA" (Test Development of natural science process skills gauges with divergent pattern to senior high school biology subjects). Based on an interview with one of the teachers in Tarakan Timur, he stated that teachers had very little 
information about the natural science process skills; in learning and scriptwriting the questions and they tend to use the lecture method and used questions that only refers to indicators leading to a few of skills of science process only.

Based on this background, we concluded that analysis on the natural science process skills of Natural Science questions on the fifth grade of Elementary School in Tarakan Timur is necessary to be studied. Given this research, teachers could have feedback on how should natural science process skills be applied in writing an evaluation tool.

\section{METHODS}

\section{A. Research Design}

Qualitative descriptive study method was used in this study. Qualitative study is the collection, analysis, and interpretation of comprehensive narrative and visual data to obtain views on particular phenomena for the purpose of a deep understanding of environmental phenomena, processes, and trust.

\section{B. Time and place of study}

The study was conducted at elementary schools in Tarakan Timur in 2017.

\section{Population and sample}

The population of this study was the fifth grade elementary school teachers in Tarakan Timur district. The sample of this study was teachers at SDN 047, SDN 007, SDN 031, SDN 016 and SDN 027 Tarakan. The sampling technique was done in purposive sampling with consideration that these four schools are able to represent the elementary schools in Tarakan Timur.

\section{Reserach Instrument}

The instruments used in this study were a checklist sheet of natural science process skills, teachers' interview on learning evaluation tools.

\section{E. Data Collection Technique}

Data collection techniques in this study were the use of students' midterm exams (UTS) of the fifth grade natural science subjects at schools selected as sample only and interviews with the teachers at the schools.

\section{F. Data Analysis Techniques}

Further analysis was done to the following obtained data:

- The data obtained from the natural science midterm exams of the fifth grade students are analyzed by examining the items whether they fulfill the aspect of natural science process skills or not, i.e. basic process skills (observing, comparing, classifying, communicating, modeling, data recording); intermediate process skills (inferring and predicting); and further process skills (making hypotheses, designing experiments, interpreting the data).
- The data obtained from interviews with teachers, i.e. the completeness of evaluation tools will be analyzed with descriptive qualitative method.

\section{RESULTS AND DisCUSSION}

The midterm exam questions of the natural science subject in the fifth grade consisted of several parts. For midterm exam of Natural Science subject at SDN 016 Tarakan of the fifth grade consisted of 20 multiple choice questions, 10 short answer questions and 5 essay questions. The midterm exam of Natural Science subject at SDN 007 Tarakan consisted of 20 meatier and 5 essays. Then, the questions on SDN 027 Tarakan consisted of 10 short answer questions and 5 essay questions while the midterm exam of Natural Science subject at SDN 031 Tarakan consisted of 20 multiple choice questions and 5 short answer questions.

The Natural Science process skills analysis shows that not all aspects of natural science process skills were included in midterm exam questions; there were some aspects of Natural Science process skills that were not included in the questions.

The data of natural science process skills that are not included in fifth grade natural science process skills are as follows:

\section{A. Basic Skills}

\section{1) Observing}

The first aspect of natural science process skills was observing. The following is observation aspect data of natural science process skills at the midterm exam of natural science in class V SD that is presented in Table 1 below.

TABLE I. QUESTIONS ON OBSERVATION ASPECT

\begin{tabular}{|l|l|l|l|}
\hline School & $\begin{array}{c}\text { Number of } \\
\text { Questions on } \\
\text { Observation } \\
\text { Aspect }\end{array}$ & $\begin{array}{c}\text { Total } \\
\text { Question }\end{array}$ & $\begin{array}{c}\text { Percentage } \\
(\%)\end{array}$ \\
\hline SDN 007 Tarakan & 6 & 25 & 6 \\
\hline SDN 016 Tarakan & 11 & 35 & 31.4 \\
\hline SDN 027 Tarakan & 3 & 15 & 20 \\
\hline SDN 031 Tarakan & 4 & 25 & 16 \\
\hline
\end{tabular}

Based on these data, the midterm exam questions of SDN 016 Tarakan have the most dominant aspect of observation. Observation is an activity that involves the five senses. The following is one of the question examples from observation aspect:

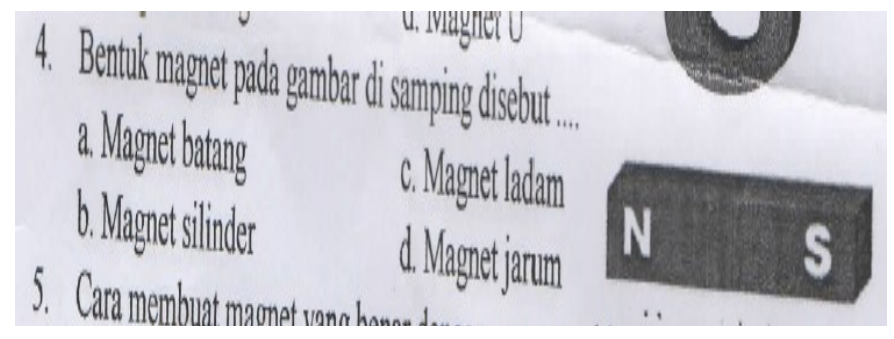

Fig. 1. Question Examples from observation 


\section{2) Classifying}

The second natural science process skills is classifying. The following is classification aspect data of natural science process skills at the midterm exam of natural science in class V SD. They are presented in Table 2 below.

TABLE II. QUESTIONS ON CLASSIFICATION ASPECT

\begin{tabular}{|l|l|l|l|}
\hline School & $\begin{array}{c}\text { Number of } \\
\text { Questions on } \\
\text { Classification } \\
\text { Aspect }\end{array}$ & $\begin{array}{c}\text { Total } \\
\text { Question }\end{array}$ & $\begin{array}{c}\text { Percentage } \\
\mathbf{( \% )}\end{array}$ \\
\hline SDN 007 Tarakan & - & 25 & 0 \\
\hline SDN 016 Tarakan & 2 & 35 & 5.7 \\
\hline SDN 027 Tarakan & 1 & 15 & 6.7 \\
\hline SDN 031 Tarakan & - & 25 & 0 \\
\hline
\end{tabular}

Based on Table 2, the schools that included classification aspect questions are SDN 016 and 27 Tarakan. The following is one of the question examples from the classification:

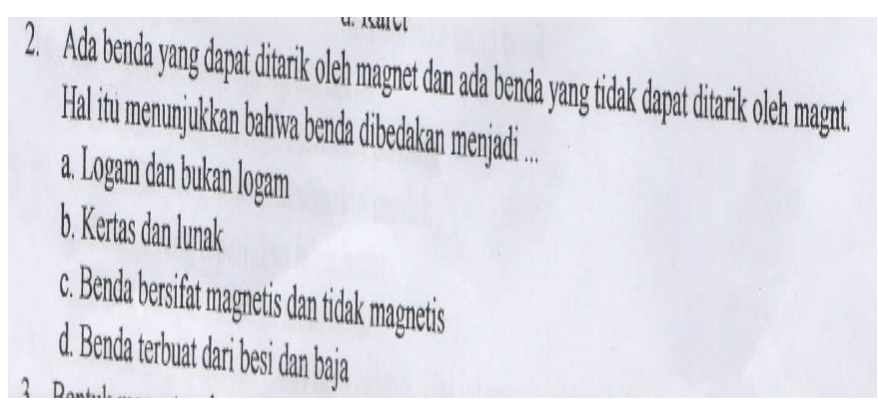

Fig. 2. Question examples from classification

\section{3) Inferring}

The next natural science process skill is to infere. The science process skill at inference aspect of the fifth grade's midterm exam questions are presented in Table 3 below.

TABLE III. Questions on Inference Aspect

\begin{tabular}{|l|l|l|l|}
\hline School & $\begin{array}{c}\text { Number Of } \\
\text { Questions On } \\
\text { Inference } \\
\text { Aspect }\end{array}$ & $\begin{array}{c}\text { Total } \\
\text { Question }\end{array}$ & $\begin{array}{c}\text { Percentage } \\
\mathbf{( \% )}\end{array}$ \\
\hline SDN 007 Tarakan & 1 & 25 & 4 \\
\hline SDN 016 Tarakan & 3 & 35 & 8.6 \\
\hline SDN 027 Tarakan & 4 & 15 & 26.7 \\
\hline SDN 031 Tarakan & 5 & 25 & 20 \\
\hline
\end{tabular}

Based on these data, the midterm exam questions with most numerous aspect of inference is SDN 031 Tarakan. Inference is a skill to make tentative conclusions related to the hypothesis. The following is one of the question examples from inference aspect.

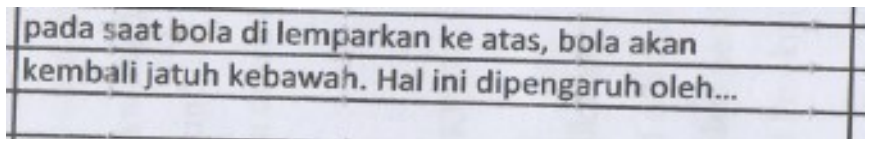

Fig. 3. Questions on Inference Aspect

\section{4) Predicting}

The next natural science process skills is to predict. The science process skill at prediction aspect of fifth grade's midterm exam questions is presented in Table 4 below.

TABLE IV. QUESTIONS ON PREDICTION ASPECT

\begin{tabular}{|c|l|l|l|}
\hline School & $\begin{array}{c}\text { Number of } \\
\text { Questions on } \\
\text { Prediction } \\
\text { Aspect }\end{array}$ & $\begin{array}{c}\text { Total } \\
\text { Question }\end{array}$ & $\begin{array}{c}\text { Percentage } \\
\mathbf{( \% )}\end{array}$ \\
\hline SDN 007 Tarakan & 1 & 25 & 4 \\
\hline SDN 016 Tarakan & - & 35 & 0 \\
\hline SDN 027 Tarakan & - & 15 & 0 \\
\hline SDN 031 Tarakan & - & 25 & 0 \\
\hline
\end{tabular}

Based on these data, the school that included the prediction aspect in its midterm exam questions is SDN 007 Tarakan. Prediction is an allegation to several instances of an event in the future that has been known. The following is one of the question examples from prediction aspect.

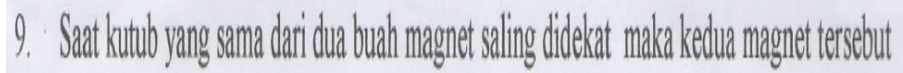 akall.}

Fig. 4. Questions on prediction aspect

\section{5) Designing the experiments}

The next natural science process skill is to design the experiments. The process skill in aspect of designing experiments in fifth grade's midterm exam questions on natural science is presented in Table 5 below.

TABLE V. Questions on Designing the Experiment Aspect

\begin{tabular}{|l|l|l|l|}
\hline School & $\begin{array}{c}\text { Number of } \\
\text { Questions on } \\
\text { Designing the } \\
\text { Experiment } \\
\text { Aspect }\end{array}$ & $\begin{array}{c}\text { Total } \\
\text { Question }\end{array}$ & $\begin{array}{c}\text { Percentage } \\
\mathbf{( \% )}\end{array}$ \\
\hline SDN 007 Tarakan & 1 & 25 & 4 \\
\hline SDN 016 Tarakan & - & 35 & 0 \\
\hline SDN 027 Tarakan & - & 15 & 0 \\
\hline SDN 031 Tarakan & 1 & 25 & 4 \\
\hline
\end{tabular}

Based on these data, the schools that included the aspect of designing experiment in their midterm exam questions are SDN 007 and SDN 031 Tarakan. The following is one of the question examples from aspect of designing the experiment.

pembuatan magnet dengan menempelkan benda
benda yang terbuat dari logam dan ditempelkan
pada magnet dilakukan dengan cara...

Fig. 5. Questions on Designing the Experiment Aspect 
At the fifth grade's midterm exam questions, the available aspect of process skills are aspects to observe, classify, infere, predict and design the experiments, in addition to the questions are categorized as memorization questions and recall as well as questions that are not categorized as natural science process skills.

Based on the interviews with the fifth grade science teachers, there was only one teacher who has ever heard the term of "natural science process skills', while the other teachers never heard the term. However, in learning process and in making question script writing, the teachers have implemented some aspects of the natural science process skills such as observing, classifying, and others. In practice, in writing the midterm examination questions in schools, the teachers have written the questions based on learning indicators, as well as based on the students' understanding level to the subjects that has been taught. It is proven from table of specification of questions that have been made by the teachers in writing midterm examination questions. Some question indicators use the verb containing operational aspects of the natural science process skills. Multiple choice questions, short answer questions or essay questions can be used to measure the process skills. This is in accordance with [5] who stated that multiple choice questions can be used to measure the ability to observe, to know the methods, to interpret, to assess the methods, to classify, to infer, to predict, and to design experiments. Therefore, the multiple choice questions have the potential to be developed as a measuring tool of process skill, namely by generating aspects of natural science process skills in the question item.

Natural science learning should use natural science process skills. This is in accordance with one of the goals of natural science education and curriculum requirements. The Educational Objectives are as expressed by [6] that the curriculum in elementary and secondary schools emphasize the use of natural science process skills approach in teaching the natural science. In addition to the implementation of learning, a teacher must also evaluate/assess at every teaching and learning activity. The assessment of natural science process skills can not be separated in learning process of natural science, it is supported by Trihastuti in [7] that the assessment on process skills should always be done to develop students' skills.

In writing the midterm examination questions, the questions made by the teachers are formed in institution known as school affiliation/school group. One group consists of several schools. The constraint that hinders the teachers in making the questions is the lack of reference that can be used in writing the questions both in textbooks and in the knowledge-based to write questions on Natural Science Process Skills [8]. There are three aspects that must be prepared by the teachers to write questions with Natural science process skills, namely: they should have the skills or master the natural science process skills, students need to be guided and given the opportunity to practice the natural science process skills, and the students' progress in implementing the natural science process skills should be assessed by their teacher.

\section{CONCLUSION AND SUGGestion}

\section{A. Conclusion}

Generally, the midterm exam questions of the fifth grade on natural science subject already contain some aspects of the natural science process skills namely observing, classifying, inferring, predicting and designing the experiments.

\section{B. Suggestion}

Further study on the development of test/question-based natural science process skills and learning with the use of natural science process skills approach should be done.

\section{REFERENCES}

[1] A. Susanto, "Teori Belajar \& Pembelajaran di Sekolah Dasar", Jakarta: Kencana, 2013.

[2] Trianto, "Model Pembelajaran Terpadu", Bumi Aksara: Jakarta, 2014

[3] E. Widayanti, "Pengembangan tes keterampilan proses sains dasar SD/MI", Dinamika Penelitian, Vol. 16, No. 1, Juli 2016.

[4] B. Subali, "Pengembangan tes pengukur keterampilan proses sains pola divergen mata pelajaran biologi SMA", Presented in the Proceeding of National Seminar of Biology, Environment and Education, Biology Department, FMIPA, Universitas Negeri Yogyakarta, 4 Juli 2009.

[5] S. Supranata, "Panduan Penulisan Tes Tertulis Implementasi Kurikulum 2004”, Bandung: PT Remaja Rosdakarya Offset, 2004.

[6] N. Y. Rustaman, "Perkembangan Penelitian Pembelajaran Berbasis Inkuiri Dalam Pendidikan Sains”, Bandung: UPI, 2005.

[7] Mahmudin, "Pelaksanaan penilaian keterampilan proses sains", Online at http://mahmuddin.wordpress.com/2010/04/10/pelaksanaan-penilaian keterampilan-proses-sains/ [accessed on March 22, 2017], 2010.

[8] W. Prabawati, dan Wahyu, "Keterampilan proses sains guru IPA", Scientific Meetng Proceeding XXLX Jateng dan DIY, Yogyakarta 25 April 2015. 